\title{
An Investigation on the Heavy Metal Tolerance and Antibiotic Profile of the Pantoea agglomerans UCP1320
}

\author{
Leonila Acioly ${ }^{1}$, José Carlos Vilar ${ }^{2}$, Aline Barbosa da Silveira ${ }^{3}$, Fabiola Carolina Gomes de \\ Almeida ${ }^{4}$, Rosileide F.S. Andrade ${ }^{4}$ and Galba Maria de Campos-Takaki ${ }^{* *}$ \\ ${ }^{1}$ Biological Sciences, Federal University of Pernambuco, 50670-420, Recife, PE, Brazil \\ ${ }^{2}$ Autarchy of Higher Education of Garanhuns (AESGA), 55295-380 Garanhuns, \\ Pernambuco, Brazil \\ ${ }^{3}$ Faculty of Guararapes, 54400-160 Jaboatão, PE, Brazil \\ ${ }^{4}$ Nucleus of Research in Environmental Sciences and Biotechnology, Catholic University of \\ Pernambuco, 50050-590, Recife, PE, Brazil \\ *Corresponding author
}

\section{A B S T R A C T}

The resistance of bacteria to antibiotics is an emerging public health concern due to antibiotics being widely available and used without proper prescription. The introduction

\section{Keywords}

Heavy metal resistance, Antibiotic susceptibility, Pantoea agglomerans.

\section{Article Info}

Accepted:

28 September 2017

Available Online:

10 November 2017 of heavy metals in various forms in the environment may cause considerable changes in the structure and function of microbial communities. In the last decade, several studies reported that the resistance of bacteria to antibiotics can occur in the environment because of multidrug resistance or cross-resistance to metals and co-regulation of airway resistance. The aim of this study is to determine the antimicrobial resistance profile patterns to 15 antibiotics and heavy metals $\left(\mathrm{Zn}^{+2}, \mathrm{Cu}^{+2}\right.$ and $\left.\mathrm{Cd}^{+2}\right)$ by Pantoeaagglomerans bacteria. The (MIC) of the heavy metals was varied from $200 \mu \mathrm{g} / \mathrm{mL}$ to $2200 \mu \mathrm{g} / \mathrm{mL}$. The results showed that the bacteria were resistant to $\mathrm{Zn}^{+2}, \mathrm{Cu}^{+2}$ and $\mathrm{Cd}^{+2}$, considering the MIC values compared with the strain Escherichia coli K-12 used as control. $P$. agglomeransshowed an antibiotic profile of resistance to Cefepime, Cefotaxime, Cefpodoxime, Clindamycin, and Amikacin, and sensitivity to Penicillin, and other antibiotics, thus suggesting that genetically-determined systems for resistance to toxic heavy metals was observed.

\section{Introduction}

Bacteria present in the environment, both aquatic and in the soil, may be indigenous or result from hospital and sewage contamination, such as human and animal feces, which is usually discharged into the aquatic environment. Polluted sewage contains large amounts of pathogenic bacteria.
These bacteria present various ways of infecting humans, and can be ingested, inhaled or come into contact with wounds (Schlusener and Bester, 2006; Matyar, 2012).

There are also several antibiotics used in animal feed to promote weight gain. Many 
countries have implemented antimicrobial resistance and antimicrobial surveillance programs to monitor these factors in animals raised for meat (Akinbowal et al., 2007).

The potential for antibiotic-resistant bacteria developing has raised social concerns that has led to the intensive investigation of the influence of antibiotics on human health and ecosystems (Kimet al., 2011; Matyar, 2012). In the last decade, several studies have reported that patterns of antibiotic resistance are becoming a global problem (Stachowiak et al., 2011; Matyar, 2012).

Studies have demonstrated an additional mechanism that keeps bacteria resistant to antibiotics in the environment due to multidrug or cross-resistance to metals or coregulation of resistance pathways (Stepanauskas et al., 2005).

Therefore, it seems likely that exposure to metal may directly select the bacteria resistant to metals, as a co-selection for antibiotic resistant bacteria. Metals, such as copper and zinc and their chemical derivatives, also have antimicrobial activity (Antunes et al., 2003). Animal feed is often supplemented with copper and/or zinc salts because they promote growth. There is concern that metal contamination functions as a selective agent in the proliferation of antibiotic resistance (Baker-Austin et al., 2006). Heavy metals can enter the food chain; in particular fish and crustaceans, and these contaminants can be introduced into the aquaculture system when fish meal bases are used as these can produce soluble contaminants such as heavy metals and polychlorinated biphenyls (Erickson, 2002).

There are three main strategies by which microorganisms can develop resistance to drugs: they produce enzymes that are capable of rendering the antimicrobial unfeasible; they prevent the drug reaching its target, through efflux pumps or membrane permeability and; they alter the molecular target of the antimicrobial (Freitas et al., 2017). In general, after the microorganism develops a better resistance strategy, the new genes that confer resistance are disseminated between organisms of the same species or different species by means of different gene transfer strategies (March-Rosselló, 2017).

Mutations can spread horizontally among bacteria by processes such as conjugation or transduction. Drug resistance is often carried by plasmids or by small segments of DNA called transposons, which can jump from one piece of DNA to another. Some resistance plasmids can be transferred between bacterial cells in the same population and between different but closely related bacterial populations (De Maayer et al., 2012).

Being resistant to antimicrobial agents, including heavy metals, is important for the survival of bacteria in contaminated environments. Resistance genes are exchanged between bacteria living in areas contaminated by heavy metals. Therefore, it can be concluded that the natural selective pressure imposed by heavy metals can, indirectly, develop bacterial resistance to antibiotics (Fard et al., 2011). This study sets out to to determine the resistance profile of Pantoea sp.to antibiotics and heavy metals in order to investigate the resistance relationship to antimicobrials.

\section{Materials and Methods}

\section{Identification of Microorganism}

The isolate of a bacterium was characterized by phenotypic, biochemical and Gram staining, oxidase and catalase, motility, glucose reactions and gelatin liquefaction tests (Mardaneh and Dallal, 2013). 


\section{Antibacterial Susceptibility Test}

Antibacterial susceptibility testing was performed by agar diffusion (Bauer et al., 1996) using Müller-Hinton medium (Difco). During the tests, the bacterial isolate was inoculated in LB medium (Tryptone, $10 \mathrm{~g}$, Yeast Extract, $5 \mathrm{~g}, \mathrm{NaCl}, 19 \mathrm{~g}, 1000 \mathrm{~mL}$ distilled water) at $30^{\circ} \mathrm{C}$ for $24 \mathrm{~h}$, respecting the turbidity of the MacFarland 0.5 scale (approximately $1.5 \times 108$ CFU.mL-1). A sterile swab was soaked in the culture, removing excess liquid, and seeded uniformly on plates containing Müller-Hinton agar. The antimicrobial discs were deposited equidistantly on the surface of the inoculated medium. A total of 15 antibiotic disks belonging to 9 different classes were used in this study, including Ertapenem (ETP, 10 $\mu$ g), Oxacillin (OXA, 1 $\mu \mathrm{g}$ ), Cefotaxime (CFX, $5 \mu \mathrm{g}$ ), Cefepime (CPM, 30 $\mu$ g), Cefpodoxime (ERI, $15 \mu \mathrm{g})$, Nalidixic Acid (10 $\mu \mathrm{g})$, Gentamicin (GEN, $10 \mu \mathrm{g}$ ), Amicacin (AMI, $30 \mu \mathrm{g}$ ), Erythromycin (ERI, $15 \mu \mathrm{g}$ ) NAL, $30 \mu \mathrm{g}$ ), Ciproflaxin (CIP, 5 $\mu \mathrm{g}$ ), Tigecycline $(\mathrm{TGC}, 15 \mu \mathrm{g})$ and Clindamycin (CLI, $2 \mu \mathrm{g}$ ). The plates were incubated at $37^{\circ} \mathrm{C}$ for $24 \mathrm{~h}$ and after that period the inhibition halos were measured, in millimetres (mm), by the diameter of the zone of inhibition around the disks, and characterized as sensitive (S), intermediate (I) and resistant (R) according to the Clinical and Laboratory Standards Institute/ 2007. Control strains were Escherichia coli ATCC 25922, Pseudomonas aeruginosa ATCC 27853, Escherichia coli ATCC 25922 and Staphylococcus aureus ATCC 25923.

\section{Minimal Inhibitory Metal Concentration Test (MIC)}

Minimal inhibitory concentration (MIC) tests on the heavy metals were conducted using the Akinbowale methodology (2007). The inoculum was prepared as described above and used for dilution tests on Müller-Hinton Agar containing different concentrations of $\mathrm{Cd} 2, \mathrm{Cu} 2$, and $\mathrm{Zn} 2$ in the form of the salts of Cadmium Chloride, Copper Sulphate and Zinc Sulfate, respectively. The stock solutions of the metals were made in distilled water and sterilized using a $0.22 \mu \mathrm{m}$ syringe to filter them into sterile glass vials which were then stored at room temperature. Dilutions in Müller-Hinton Agar media followed the concentrations of $200 \mu \mathrm{g} / \mathrm{ml}$ to $2200 \mu \mathrm{g} / \mathrm{ml}$ of each metal. The plates were incubated with $10 \mu \mathrm{L}$ of the inoculum at $30^{\circ} \mathrm{C}$ for $24 \mathrm{~h}$. Samples were considered resistant when MIC values exceeded those of the control organism, Escherichia coli K-12, described by Akinbowale et al., (2007) and Ansari and Malik (2007).

\section{Results and Discussion}

The genus Pantoea belongs to the family Enterobacteriaceae and currently comprises nineteen species of Gram-negative bacteria, with yellow or beige pigmentation and mobility. Members of this genus have been isolated from a wide variety of environments including soil, water, dust, dairy products, meat, fish, insects, humans and animals. Most often they are found associated with a wide variety of host plants, such as nonpathogenic endophytes or epiphytes, the leaves, stems and roots of which they colonize (De Maayer et al., 2012).

The bacteria were grown on nutrient agar (AN) for 24 hours at $30^{\circ} \mathrm{C}$. The colonies obtained had the following macroscopic characteristics: circular, smooth colonies, irregular and flat borders, $1 \mathrm{~mm}$ in diameter and had a yellow pigment. Microscopic examination revealed there to be a Gramnegative bacillus with rounded ends. They were seen to be alone or in pairs. It is mobile, catalase +, facultative anaerobic, nonfermenting glucose. These results corroborate 
those found by Silini-Cherif et al., (2012) in the identification of a lineage of Pantoea agglomerans Ima2 isolated from wheat rhizosphere.

Fujikawa and Akimoto (2011) also show similar results for Pantoea agglomerans. Both studies present yellow pigment production by microorganisms. These results are also common to the strains of $P$. ananatis, $P$. dispersa and P. stewartii (Delétoile et al., 2009).

The results of antibiotic susceptibility showed that Pantoeasp was sensitive to most antibiotics and intermediate to ertapenem and erythromycin and resistant to the three antibiotics tested in the class of cephalosporins (cefotaxime, cefepime, cefpodoxime), an aminoglycoside antibiotic (Amikacin) and a licosamide (clindamycin) (Table 1). In heavy metal tolerance tests, Pantoea sp.showed resistance to the three $\mathrm{Cu}>\mathrm{Zn}>\mathrm{Cd}$ tested metals (Table 2).

Nath et al., (2013) presented results, where antibiotics of the cell-phosporins and aminoglycyses groups were inefficient at controlling bacterial isolates of the genera Pseudomonas, Klebsiella and Bacillus, resistant to zinc, copper and lead. Akimbowale et al., (2007) on isolating strains of Pseudomonas and Aeromonas found that these were also resistant to drugs in the cephalosporin group, and also showed similarities in resistance to metals.

Table.1 Susceptibility to antibiotics of Pantoea agglomerans isolated from laundry effluent

\begin{tabular}{llccccc}
\hline \multicolumn{1}{c}{$\begin{array}{c}\text { Antibiotic } \\
\text { Class }\end{array}$} & \multicolumn{1}{c}{ Antibiotic } & $\begin{array}{c}\text { Disk [C] } \\
\boldsymbol{\mu g} / \mathbf{m L}\end{array}$ & $\mathbf{R}$ & $\mathbf{I}$ & $\mathbf{S}$ & $\begin{array}{c}\text { Results } \\
\text { (Halo) }\end{array}$ \\
\hline & Penicillin & 10 & $\leq 28$ & - & $\geq 29$ & $30 \mathrm{~mm}(\mathrm{~S})$ \\
& Ertapenem & 10 & $\leq 15$ & $16-18$ & $\geq 19$ & $17 \mathrm{~mm}(\mathrm{I})$ \\
Penicillins & Oxacillin & 1 & $\leq 10$ & $11-12$ & $\geq 13$ & $18 \mathrm{~mm}(\mathrm{~S})$ \\
& Nalidixic Acid & 30 & $\leq 13$ & $14-18$ & $\geq 19$ & $24 \mathrm{~mm}(\mathrm{~S})$ \\
Quinolones & Ciproflaxin & 5 & $\leq 15$ & $16-20$ & $\geq 17$ & $30 \mathrm{~mm}(\mathrm{~S})$ \\
Cephalosporins & Cefotaxime & 5 & $\leq 14$ & $15-17$ & $\geq 18$ & $(\mathrm{R})$ \\
& Cefepime & 30 & $\leq 14$ & $15-17$ & $\geq 18$ & $(\mathrm{R})$ \\
& Cefodoxime & 10 & $\leq 17$ & $18-20$ & $\geq 21$ & $(\mathrm{R})$ \\
& Gentamicin & 10 & $\leq 12$ & $13-14$ & $\geq 15$ & $24 \mathrm{~mm}(\mathrm{~S})$ \\
Aminoglycosides & Tobramyicin & 10 & $\leq 12$ & $13-14$ & $\geq 15$ & $20 \mathrm{~mm}(\mathrm{~S})$ \\
& Amikacin & 30 & $\leq 12$ & $15-16$ & $\geq 17$ & $(\mathrm{R})$ \\
Glycopeptides & Vacomicin & 30 & $\leq 14$ & $15-16$ & $\geq 17$ & $20 \mathrm{~mm}(\mathrm{~S})$ \\
Glycylcycline & Tigecycline & 15 & $\leq 19$ & $20-27$ & $\geq 28$ & $30 \mathrm{~mm}(\mathrm{~S})$ \\
Macrolides & Erythromycin & 15 & $\leq 13$ & $14-22$ & $\geq 23$ & $15 \mathrm{~mm}(\mathrm{I})$ \\
Amphenicol & Chloramphenicol & 30 & $\leq 12$ & $13-17$ & $\geq 18$ & $24 \mathrm{~mm}(\mathrm{~S})$ \\
Lincosamides & Clindamycin & 2 & $\leq 14$ & $15-20$ & $\geq 21$ & $(\mathrm{R})$ \\
\hline
\end{tabular}

Reference: (CLSI, 2006). R- resistant; I- Intermediate; S- sensitive

Table.2 Resistance of Pantoea agglomerans to different concentrations of heavy metals

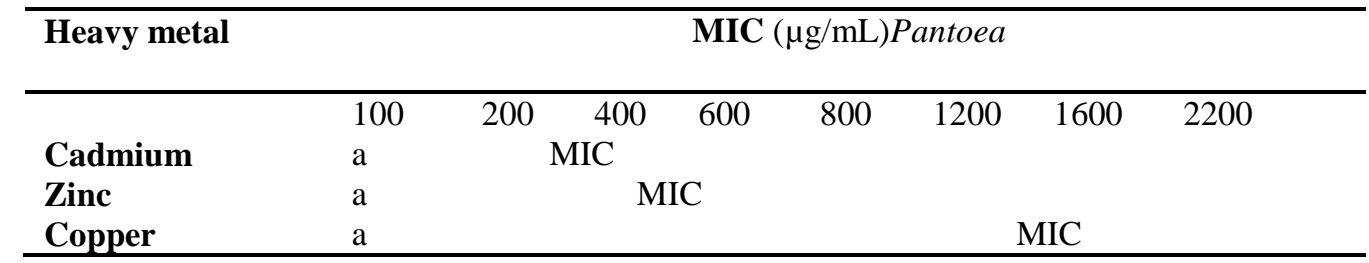

MIC (Minimum Inhibitory Concentration).

(a) MIC of the strain Escherichia coli K12 (Akinbowale et al., 2007) 
Sharma et al., (2012), when analyzing a case of septic arthritis caused by Pantoea agglomerans, found that this species did not respond to treatment with amikacine, gentamicin, cotrimoxazole, ciprofloxacin, tobramycin, ampicillin and ceftamizine.

The resistance of Enterobacterium species to a broad spectrum of cephalosporins is already known, and because it is mediated by a chromosomal overproduction of AmpC [beta] -lactamases (Aibinu et al., 2012).

Such enzymes are normally encoded on the chromosome of Gram-negative bacteria, including Citrobacter, Serratia, and Enterobacteria species in which their expression is usually inducible, but may also occur in Escherichia coli. However, AmpC [beta] -lactamases can also be transported in plasmids (Philipponet al., 2002). The selection of resistance determinants in the environment could occur even in the absence of the antimicrobial.

Many multiple-resistance determinants are capable of simultaneously conferring resistance to compounds belonging to various classes of chemical compounds, such as detergents and antiseptics (Chadha, 2012).

Other studies have shown that selection of antimicrobial resistance determinants could occur due to heavy metal pollution and chemicals (Getanda et al., 2017). Therefore, the selection of resistant bacteria could occur by selecting resistance to compounds that are not antimicrobial, but that make this selection with the same mechanism of resistance (Chadha, 2012).

The various ecological niches occupied by species of Pantoea, including plant and animal hosts, and their distinct lifestyles such as epiphytes and endophytes, are indicative of the diversification within the genus Pantoea and even among individual strains belonging to the various species of the genus. One means by which this diversification takes place is exactly because plasmids between bacteria are acquired. These plasmids carry genes that confer various phenotypes on the bacterium, including toxin production; hormone production; and virulence factors that contribute to host pathogenesis and specificity; antibiotic and heavy metal resistance and survival under adverse conditions; catabolism of Amino acids and organic acids, carbohydrates and inorganic ions; and the colonization and dissemination of these species (De Maayer et al., 2012).

The strain of Pantoea agglomerans presented resistance to the antibiotics cefotaxime, cefepime and cefpodoxime of the cephalosporin group. The group of aminoglycosides presented resistance to amikacin and clidamycin from the licosamides group. In heavy metal tolerance tests, P.agglomerans showed crossing resistance to the three metals tested at the higher levels for $\mathrm{Cu}$, followed by $\mathrm{Zn}$ and by Cd.

\section{Acknowledgements}

This work was supported by National Council for Scientific and Technological Development (CNPq), Coordination for the Improvement of Higher Level Education Personnel (CAPES), and the fellowship byFoundation for Science and Technology of the State of Pernambuco (FACEPE).

We thank to the Nucleus of Research in Environmental Sciences and Biotechnology, Catholic University of Pernambuco, Brazil,

\section{Conflict of Interest}

The authors confirms that this article content has no conflict of interest. 


\section{References}

Aibinu, I.; Pfeifer, Y.; Peters, F.; Ogunsola, F.; Adenipekun, E.; Odugbemi, T.; Koenig, W. 2012. Emergence of blaCTX-M-15, qnrB1 and aac(69)-Ibcrresistance genes in Pantoea agglomerans and Enterobacter cloacae from Nigeria (sub-Saharan Africa). J. Medical Microbiol., 61, 165-167.

Akinbowale, O.L.; Peng, H.; Grant, P.; Barton, M.D. 2007.Antibiotic and heavy metal resistance in motile aeromonads and pseudomonads from rainbow trout (Oncorhynchus mykiss) farms in Australia.Inter. J. Antimicrobial Agents,3, 177-182.

Ansari, M.I.; Malik, A. 2007. Biosorption of nickel and cadmium by metal resistant bacterial isolates from agricultural soil irrigated with industrial wastewater. Biores. Technol., 98, 3149-3153.

Antunes, W.M., Luna, A.S., Henriques, C.A., DA Costa, A.C.A. 2003. An evaluation of copper biosorption by a brown seaweed under optimized conditions. Electronic J. Biotechnol., 6, 6174-184.

Baker-Austin, C., Wright MS, Stepanauskas R, McArthur JV. 2006. Co-selection of antibiotic and metal resistance. Trends in Microbiol., 14, 176-182.

Bauer, W.A.; Kirby, W.M.; Sherris, J.C.; Turck, M.1996.Antibiotic susceptibility testing by a standardized single disk method. American J. Clinical Pathol., 45, 493-496

Chadha,T.2012.Antibiotic Resistant Genes in Natural Environment.Chadha, Agro technol.,,1-3.

De Maayer, P.; Chan, W.Y.; Blom, J.; Venter, S.N.; Duffy, B.; Smits, T.H.M.; Coutinho, T.A. 2012. The large universal Pantoea plasmid LPP-1 plays a major role in biological and ecological diversification. BMC Genomics, 13, $625,1471-2164$.
Delétoile, A. Decré, D.; Courant, S.; Passet, V.; Audo, J.; Grimont, P.; Arlet, G.; Brisse, S. 2009.Phylogeny and Identification of Pantoeaspecies and Typing of Pantoea agglomeransstrains by multilocus gene sequencing.J. Clinical Microbiol., 47, 300-310.

Erickson, B.E. (2002). More than just dioxins in food. Environmental Sci Technol.,2002, 36,267A-8A.

Fard, R.M.N.; Heuzenroeder, M.W.; Barton, M.D.2011.Antimicrobial and heavy metal resistance in commensal enterococci isolated from pigs. Veterinary Microbiol., 148, 276-282.

Freitas, D.G.;Silva, R.D.R.; Bataus,L.A.M.; Barbosa, M.S.; Braga, C.A.S.B.; Carneiro, L.C. 2017.Bacteriological water quality in school's drinking fountains and detection antibiotic resistance genes.Ann Clin Microbiol Antimicrob., 16,1-5.

Fujikawa, H.; Akimoto, R. 2011.New blue pigment produced byPantoea agglomerans and its production characteristics at various temperatures. Appl. Environ. Microbiol., 77, 172-178.

Getanda, P.; Kariuki, F.; Gitahi, N.; Onkoba, N.; Juma, G.; Kinyanjui, P.; Nyachieo, A.; Kamau, J. 2017. Genetic characterization and evaluation of antimicrobial resistance patterns of human Salmonella typhi isolates in kenyattanational hospital in Nairobi, Kenya. PathogenInfect.Dis., 3, 1-8.

Kim, K.R.; Owens, G.; Kwon, S.I. 2011.Occurence and environmental fate of veterinary antibiotics in the terrestrial environment. Water, air and soil pollution, 214, 163-174.

March-Rosselló, GA.2017.Rapid methods for detection of bacterial resistance to antibiotics.Enferm Infecc Microbiol Clin., 35, 3, 182-188. 
Mardaneh, J. and Dalla, M.M.S. 2013. Isolation, identification and antimicrobial susceptibility of Pantoea (Enterobacter) agglomerans isolated from consumed powdered infant formula milk (PIF) in NICU ward: First report from Iran.Iran J Microbiol., 5(3), 263-267.

Matyar, F. 2012. Antibiotic and Heavy Metal Resistance in Bacteria Isolated from the Eastern Mediterranean Sea Coast. Bulletin Envir. Contamination Toxicol., 89,.551-556.

Nath, S; Deb, B.; Sharma, I.; Pandey, P. 2013. Isolation and characterization of heavy metal resistant bacteria and its effect on shoot growth of Oryza sativa inoculated in industrial soil. AnnalsPlantsSci.,2, 6, 2013.

Philippon, A.; Arlet, G.; Jacoby, G.A. 2002. Plasmid-Determined AmpC-Type $\beta$ lactamases. Antimicrobial Agents Chemo., 46, 1-11.

Schlusener, M.P., Bester, K.2006. Persistence of antibiotics such as macrolides, tiamulin and salinomycin in soil Environmental Pollution, 143, 565-571.

Sharma, M.; Dogra B.B.; Misra, R.; Gandham, N.; Sardar, M.; Jadhav, S. 2012.Multidrug Resistant Pantoea agglomeransin a patient with septic arthritis- a rare report from India. Inter. J. Microbiol. Res., 4, 6,263-265.

Silini-Chérif, H.; Silini, A.; Ghoul, M.; Yadav, S. 2012.Isolation and characterization of plant growth promoting traits of Rhizobacteria: Pantoea agglomerans. Pakistan J. Biol. Sci., 15, 267-276.

Stachowiak, M.; Clark, S.E.; Templin, R.E.; Baker, K.H. 2010. Tetracyclineresistant Escherichia coli in a small stream receiving fish hatchery effluent. Water, air soil and pollution, 211, 251259.

Stepanauskas, R.; Glenn, T.C.; Jagoe, C.H.; Tuckfield, R.C.; Lindell, A.H.; McArthur, J.V.2005. Elevated microbial tolerance to metals and antibiotics in metal-contaminated industrial environments. Environ. Sci.Technol, 39, 3671-3678.

\section{How to cite this article:}

Leonila Acioly, José Carlos Vilar, Aline Barbosa da Silveira, Fabiola Carolina Gomes de Almeida, Rosileide F.S. Andrade and Galba Maria de Campos-Takaki. 2017. An Investigation on the Heavy Metal Tolerance and Antibiotic Profile of the Pantoea agglomerans UCP1320. Int.J.Curr.Microbiol.App.Sci. 6(11): 4145-4151. doi: https://doi.org/10.20546/ijcmas.2017.611.486 